\title{
Inflation expectations and consumer spending: the role of household balance sheets
}

Citation for published version (APA):

Lieb, L., \& Schuffels, J. (2019). Inflation expectations and consumer spending: the role of household balance sheets. Maastricht University, Graduate School of Business and Economics. GSBE Research Memoranda No. 022 https://doi.org/10.26481/umagsb.2019022

Document status and date:

Published: 20/08/2019

DOI:

10.26481/umagsb.2019022

Document Version:

Publisher's PDF, also known as Version of record

\section{Please check the document version of this publication:}

- A submitted manuscript is the version of the article upon submission and before peer-review. There can be important differences between the submitted version and the official published version of record.

People interested in the research are advised to contact the author for the final version of the publication, or visit the DOI to the publisher's website.

- The final author version and the galley proof are versions of the publication after peer review.

- The final published version features the final layout of the paper including the volume, issue and page numbers.

Link to publication

\footnotetext{
General rights rights.

- You may freely distribute the URL identifying the publication in the public portal. please follow below link for the End User Agreement:

www.umlib.nl/taverne-license

Take down policy

If you believe that this document breaches copyright please contact us at:

repository@maastrichtuniversity.nl

providing details and we will investigate your claim.
}

Copyright and moral rights for the publications made accessible in the public portal are retained by the authors and/or other copyright owners and it is a condition of accessing publications that users recognise and abide by the legal requirements associated with these

- Users may download and print one copy of any publication from the public portal for the purpose of private study or research.

- You may not further distribute the material or use it for any profit-making activity or commercial gain

If the publication is distributed under the terms of Article $25 \mathrm{fa}$ of the Dutch Copyright Act, indicated by the "Taverne" license above, 
Lenard Lieb, Johannes Schuffels

Inflation expectations and consumer spending: the role of household balance sheets

RM/19/022

\section{GSBE}

Maastricht University School of Business and Economics

Graduate School of Business and Economics

P.O Box 616

NL- 6200 MD Maastricht

The Netherlands 


\title{
Inflation expectations and consumer spending: the role of household balance sheets
}

\author{
Lenard Lieb* Johannes Schuffels*† \\ Maastricht University
}

This version: March 2019

\begin{abstract}
Research interest in the reaction of consumption to expected inflation has increased sharply in recent years due to efforts by central banks to kick-start demand through higher inflation expectations. We contribute to this literature by analyzing whether various components of households' balance sheets determine how consumption reacts to expected inflation. Many channels are conceivable: an increase in inflation expectations can raise consumption through direct increases in expected real wealth, e.g. for households with nominal financial liabilities. By affecting the real interest rate, expected inflation can interact with wealth if only those households can adapt their consumption to current real interest rates that are not budget constrained or sufficiently liquid to shift funds between consumption and savings. We use household-level information on balance sheets, vehicle expenditures and inflation expectations from the Dutch Central Bank's Household Survey. We find evidence for a relation between a household's expected inflation and the probability to have positive expenditures on durables. This effect is stronger for households with low net worth. We find no evidence of such effects on the amount of durable expenditures.
\end{abstract}

JEL D15, D84, E21, E31

\footnotetext{
* School of Business and Economics, Maastricht University, Tongersestraat 53, 6211LM Maastricht

${ }^{\dagger}$ Corresponding author: j.schuffels@maastrichtuniversity.nl, Tel: +31 4338 83653, Fax: +31 43 38-82000.

We thank Clemens Kool and Tom van Veen for helpful discussions. We also thank participants at the GSBE PhD-colloquium (Maastricht University), the 12th International Workshop of Methods in International Finance Network in Louvain-la-Neuve, the 12th International Conference on Computational and Financial Econometrics in Pisa, the Conference of the International Association of Applied Econometrics in Nicosia and the International Panel Data Conference in Vilnius for helpful comments.
} 


\section{Introduction}

Hypotheses on why inflation expectations can have an impact on consumption on the micro level are based on two arguments: first, inflation expectations change the real interest rate and could therefore affect interest-sensitive consumption. Second, they affect expected real wealth and therefore consumption out of real wealth. In both cases the composition of a household's balance sheet can alter the size and direction of the effect of inflation expectations on spending. Attempts to gauge this interaction in the literature have been incomplete. Several authors estimated the impact of inflation expectations on consumption. These studies have usually exploited some sort of natural experiment such as the zero lower bound or value-added tax increases to identify a causal relationship using cross-sectional (Bachmann et al., 2015; Ichiue \& Nishiguchi, 2015; D'Acunto et al. 2016) or panel data (Burke \& Ozdagli, 2013) without reaching consensus on the sign or size of the effect. So far, no analysis has credibly accounted for the potential role of the balance sheet as a moderator of the effect of price expectations on spending. The objective of this paper is to test empirically whether different components of a household's balance sheet interact with its inflation expectations in affecting realized consumer spending. To this end, we use panel data on household level balance sheets, inflation expectations and durable consumer spending from the Dutch Central Bank's (DNB) Household Survey.

While the use of micro level data to study the nexus between inflation expectations and consumer spending has allowed researchers to credibly estimate cross-sectional effects, almost no attention has been paid to analyze the economic mechanisms behind these "general" effects. Several wealth channels are conceivable. Changes in the real interest rate affect credit-financed consumption. Differences in inflation expectations can lead to differences in the perceived real interest rate both over time and across households. Borrowing conditions may differ both across households and within households over time depending on the household's balance sheet. Inflation expectations also determine expected real wealth and thus consumption out of real wealth. In case of rising inflation expectations debtors expect increases in real wealth, while creditors expect falls in real wealth. Another reason is the inflation-hedging nature of certain assets: owners of real estate and stocks are relatively well protected against devaluation effects of inflation (Fama \& Schwert, 1977, Kim \& In, 2005) whereas financial liabilities are repaid in nominal terms. Accordingly, spending of net debtors is expected to be more sensitive to changes in expected inflation than for net owners of real estate and stocks 1

Our approach departs from the literature in important ways. First, we try to identify specific economic channels that determine the effect of inflation expectations on spending. The granular information on

$1 \quad$ Other channels that are not affected by wealth have also been put forward: Wiederholt (2014) suggests that high inflation expectations could be a sign of policy uncertainty and thus depress spending. Cavallo et al. (2017) show that the existence of a relationship between inflation expectations and consumption can be explained by rational inattention: when the benefits of forming accurate expectations outweigh their costs - such as in episodes of high inflation - household spending behaviour is more sensitive to inflation expectations. 
households' balance sheet in our data set allows us to test explicitly what role balance sheets play in moderating the effect of price expectations on durable spending. Second, we analyse realized spending, rather than planned spending or attitudes towards spending. These two latter measures, often used in the literature, will likely overestimate a positive effect of inflation expectations on spending: households might be willing to consume but liquidity constraints impede them from doing so. Third, observing households over time allows us to better capture the intertemporal dimension of consumption decisions, which is particularly important if agents are forward looking and expectations play a crucial role.

Sufficient and accurate control for confounders in analyses of large scale surveys poses problems to the researcher. The DNB Household Survey contains a wide range of household characteristics. Including all characteristics that could potentially impact consumption behavior is not feasible. Selecting controls only based on personal judgement or theory might lead to omission or unnecessary inclusion of some variables. Instead we apply a data-driven post-double variable selection procedure of the type introduced by Belloni et al. (2014a). With penalized regression techniques we only select those variables that impact the dependent variable and the independent variables of interest in the data. This limits the danger of omitted variable bias while keeping the number of coefficients to be estimated as low as possible.

We find evidence for a positive relation between a household's expected inflation and the probability to consume. This effect is amplified for households with lower net worth. We find no evidence for effects of inflation expectations and its interactions with wealth along the intensive margin.

The rest of the paper is organized as follows. In section 2 we review the related literature. We discuss possible economic mechanisms that link consumption decisions, inflation expectations, and the balance sheet in section 3 . The data is presented in section 4. In section 5 we present our econometric framework and formulate key hypotheses which we investigate in section 6 .

\section{Related literature}

A number of influential contributions by Coibion, Gorodnichenko and co-authors 2012, 2015a, 2017) have led to considerable research interest in the formation of inflation expectations and their macro and microeconomic effects. They provide substantial evidence that inflation expectations by consumers, businesses and even professionals and central bankers do not satisfy the conditions for full information rational expectations. Thus, consumers make systematic forecasting errors that, according to Coibion \& Gorodnichenko (2015b), can explain some macro puzzles, such as the missing disinflation in the US after 2009. Our study connects to their research agenda by providing evidence of how consumer inflation expectations affect microeconomic choices.

More closely related to the research question at hand are previous analyses that have already tried to use micro data to estimate spending effects of inflation expectations. As stated above, no clear 
consensus has been reached on the direction or size of the effect. Bachmann et al. (2015) use repeated cross-sections of the Michigan Survey of Consumers to investigate the effect of inflation expectations of households on the degree to which these households judge the economic circumstances in the respective period as favorable for durable consumption good purchases. They find that during the zero lower bound episode higher inflation expectations had - unexpectedly if standard economic reasoning is applied - slightly negative effects on the probability for households to have positive spending attitudes. The authors perform a number of regressions in search of heterogeneities in the relationship between inflation expectations and spending attitudes, among them controlling for wealth by including binary measures of home ownership and proxying an individual's debtor status with age since young people tend to be more indebted (e.g. through study loans or mortgages) than older ones. They do not interact wealth with inflation expectations. Ichiue \& Nishiguchi (2015) approach the problem similarly, but with Japanese data and find strongly positive effects of inflation expectations on planned spending. They argue that after a long period of zero nominal interest rates, Japanese consumers have understood how inflation affects the real interest rate and therefore react. More recently, Duca et al. (2018) re-examine the same question for a large panel of households in the Eurozone. The authors find small positive effects of increased inflation expectations on attitudes to spending. While they control for household wealth, they do not examine interactions between wealth and expectations.

A very different approach has been taken by D'Acunto et al. (2016). Their paper uses a valueadded tax increase in January 2007 in Germany to estimate the effects of exogenous changes in inflation expectations. Compared to households in other European countries that did not experience the VAT increase, German households were substantially more likely to have positive attitudes towards spending in the months before the tax increase came into force. A limitation of this approach is that the price expectations of German households in November and December of 2006 contained considerably less uncertainty than households in other European countries. Households knew that a VAT increase will unambiguously increase prices of consumer products. They usually cannot form expectations with such certainty and precision. The effect of inflation expectations on consumption might differ substantially in times with less salient events or policy changes that nonetheless impact inflation.

The study most similar to ours is Burke \& Ozdagli (2013). Using survey responses on expected inflation and realized spending on a wide range of products of a panel of American households between 2009 and 2012, they find much less clear results than the studies presented above. Households do not seem to increase their durable expenditures as a result of higher inflation expectations except for car purchases. In addition, they find evidence for effects on non-durable expenditures, driven by owners of real estate. Even though we analyze durable expenditures this finding justifies our strategy of carefully investigating potential interactions of expected inflation with balance sheet variables. Burke \& Ozdagli (2013) can only observe binary measures of balance sheet variables, such as home ownership. 


\section{Mechanisms}

Next we introduce the different mechanisms through which balance sheets could affect households' spending responses to expected inflation. Potential candidates are the real interest rate and real wealth changes that result from adapted inflation expectations. Lastly, we discuss the extensive and intensive margin of the purchasing decision and their implications for our analysis.

\section{Intertemporal substitution}

Consumers adapt their spending behaviour when relative prices change by substituting the more expensive for the cheaper good. Price changes over time also change the purchasing power of consumers' income in different periods which may affect their selected intertemporal consumption bundle. These standard substitution and income effects of relative price changes can be illustrated by the following basic set-up. Consider the following intertemporal budget constraint for a household with nominal income $y_{t}$, nominal interest rate $i$ and consumption good $c_{t}$ with price $p_{t}$ in periods 1 and 2 :

$$
p_{1} c_{1}+\frac{p_{2}}{1+i} c_{2}=y_{1}+\frac{y_{2}}{1+i}
$$

By normalizing $p_{1}$ to 1 and defining $\pi^{e}=\frac{p_{2}-p_{1}}{p_{1}}$ we can rewrite the previous equation as

$$
c_{1}+\frac{1+\pi^{e}}{1+i} c_{2}=y_{1}+\frac{y_{2}}{1+i}
$$

An increase in $\pi^{e}$ raises the expected future price of the consumption good relative to its current price and lowers the real interest rate. This triggers the standard substitution effect: consumers want to increase current spending relative to future spending since the price of the good is lower in the current period. In contrast, the direction of the income effect depends on whether the consumer is borrower or saver. The lower real interest rate benefits the borrower: by transferring income from period 2 to period 1, one can increase total consumption compared to a situation with higher real interest rates. Savers lose: the income they transfer from period 1 to period 2 earns less real interest, therefore total consumption falls. Many studies assume that the substitution effect dominates for savers and they too will increase current spending, e.g. Christiano et al. (2005). Even this very basic set-up predicts differential consumption responses for households based on their balance sheet position: debtors will increase their current consumption by more than savers if their expectations about future prices rise. The qualitative conclusion does not change if future income is indexed to inflation, only the degree to which consumption is transferred to the current period would be lower.

However, not all households face the same perceived borrowing conditions. Analogous to the argument made by Bernanke (1993) for firms, households with higher net worth are generally seen as more credit- 
worthy by banks and might face better borrowing conditions. Thus, even under constant economy-wide nominal interest levels the perceived borrowing conditions for households do not only depend on their inflation expectations. The same change in inflation expectations can lead to different household-specific perceived borrowing conditions if the balance sheet quality differs. Applying this idea to the relationship between inflation expectations and consumption is not new: Ichiue \& Nishiguchi (2015) make the same point in their analysis, but cannot convincingly test it.

\section{Real wealth}

An increase in expected inflation can lead to a reduction in expected real wealth since the expected price level of the future period is now higher than before while nominal wealth has remained constant. For debtors the opposite is true: higher inflation will reduce the expected real value of debt and thus increase their expected net worth. The observation that changes in wealth have effects on consumption has been widely documented in the past using both macro and micro data (Case et al., 2005, Mian et al., 2013).

However, this view on the real wealth channel may be too simplistic. Inflation expectations may have nonlinear effects on consumption depending on real wealth because there are differences in the sensitivity of various assets and liabilities to inflation. For many households real estate or financial investments serve as a protection against inflation. Fama \& Schwert (1977) have shown that returns on real estate protect fully against unanticipated as well as anticipated inflation. They regressed the expected nominal return of several assets on expected inflation. If the coefficient of expected inflation is equal to one, the nominal return compensates for losses in real returns on average. Thus, the expected real return does not change when inflation expectations change. More recent studies have confirmed the long-run inflation hedging nature of real estate and found mixed evidence for the short-run analysis conducted by Fama \& Schwert (1977) Anari \& Kolari, 2002, Hoesli et al. 2008). While Fama \& Schwert (1977) cannot confirm the inflation hedging nature of stocks in the short term, later studies came to the conclusion that in the long run stock investments have the same inflation hedging property as real estate (Schotman \& Schweitzer, 2000 Kim \& In, 2005). Households with substantial part of their wealth invested in these asset classes might not regard higher future inflation as a threat to their future wealth since their investment strategy is designed to protect against such developments. Even if this protection is not perfect, it surely holds to a larger degree than, say, for cash holdings. Households with cash holdings as their only assets have no way of protecting themselves against losses in the real value of their cash holdings due to inflation. Similarly, debt contracts usually specify a nominal amount that has to be repaid. Here, higher inflation expectations lead to an expected decrease in the real value of debt, i.e. increasing real wealth. To summarize, households who invested large parts of their wealth into real estate or financial investments are expected to exhibit less sensitivity to inflation expectations in their 
consumption decisions. Households with relatively large exposure to cash or debt may react more strongly since their expected real wealth necessarily changes in response to changing inflation expectations.

Any of the above channels imply that individuals with a different balance sheet composition (both concerning the relative sizes of assets and liabilities and the relative importance of specific classes of assets and liabilities) but identical inflation expectations will exhibit differing spending behaviour.

\section{Extensive and intensive margin}

It is unclear whether we should expect the effects outlined above to materialize on the extensive or the intensive margin of a purchase. The extensive margin concerns the probability of purchasing in a given year or not. The intensive margin concerns the amount a household spends on a durable good conditional on the decision to purchase. In theory, the mechanisms could play a role in both decisions a household has to make.

When emphasizing the extensive margin, we assume that households' tastes regarding durable goods are relatively fixed over time and the element of the decision that is subject to variations in expected inflation is the timing of the purchase. In a year in which a household has higher inflation expectations it might be more likely to buy the durable item it had already planned to acquire for longer. This reasoning is consistent with some results that emerged from the literature analyzing the "hot potato" effect of inflation. The "hot potato" effect refers to the observation that consumers spend their money faster in times of high inflation. In a search based monetary theory model, Liu et al. (2011) find that inflation affects especially the extensive margin of the purchasing decision.

Intuitively, the intensive margin matters more if we take the view that the timing of the purchase is determined by other factors. In a low inflation environment households might not let their inflation expectations determine important decisions. Rather, they will expect small changes in real wealth or the real interest rate and thus adapt their spending accordingly by rather limited amounts. That means households adapt their preferences in reaction to changes in expected inflation.

These considerations give rise to an econometric specification in which we allow for interactions between households' expected inflation and its different balance sheet components. Section 5 outlines how we aim to test the different mechanisms and what effects they would imply for our empirical analysis. By accounting for this interaction we depart from the previous literature on the topic. All of the aforementioned authors have stressed in their papers that wealth might play a role in the relationship between expected inflation and (durable) consumption. Our key contribution consists of testing this channel in a novel and appropriate way. 


\section{Data}

Our aim in this study is to explore the interaction between households' inflation expectations and their balance sheets in determining spending decisions. Information on all three variables needs to be at the household level and available for the same household over several years.

Contrary to previous studies, we set out to analyze realized consumer spending instead of attitudes to spending in general. However, specific survey answers on total (durable) expenditures might involve substantial measurement error. It is much easier to recall expenditures for specific durable goods since these items are seldom purchased and each individual purchase accounts for a substantial fraction of total spending of that period.

Additionally, our analysis requires balance sheet information on the household level. The literature on wealth effects on consumption concludes that different types of assets and liabilities might have different effects on consumer expenditures (Case et al., 2005). To provide a thorough account of the interaction we want to analyze individual balance sheet components as well as the net financial position of the households.

For the above reasons we make use of the DNB Household Survey (DHS) administered by CentERdata (Tilburg University, The Netherlands) and issued by the Dutch Central Bank (DNB). It includes households' self-reported balance sheets and their expected one year ahead inflation rate. Part of the selfreported balance sheet consists of vehicles owned by the household. We use this information to construct a variable of household vehicle expenditures (more details below). The DHS is an unbalanced panel of 12.169 households with annual observations between 1993 and 2017. More than one household member can respond to the survey. Since the balance sheets are aggregated at the household level, we only use responses to household member specific questions from the first member of the household. This results in 48.921 household-year observations from which we construct our variables of interest.

We want to stress the unique fit of this dataset for our purposes. To our knowledge, no previous study has made use of such extensive balance sheet information to analyze the effect of inflation expectations on realized consumer spending.

In the following, we give an overview of the different variables of interest and provide descriptive statistics.

\section{Measuring durable consumption}

In recent papers many authors concentrate on analyzing the effects of inflation expectations on durable consumption (Burke \& Ozdagli, 2013, Bachmann et al., 2015, Ichiue \& Nishiguchi, 2015). We follow the literature in this respect. Durable consumption is the component of aggregate consumption most likely to be affected by variations in the real interest rate since it is more likely to be credit financed than 
expenditures on non-durable goods. Additionally, demand for non-durable consumption is less elastic to changes in macroeconomic conditions in general.

The DNB Household Survey does not include questions on expenditures on different classes of durable goods. However, households do report a large part of their assets. Among those are vehicles, such as cars, motorbikes and boats. For each of these items households report the purchasing price. We construct our expenditure variable by recording each time the purchasing price changes. For the extensive margin, the consumption variable takes the value 0 in case there is no change in the purchasing price and 1 in case there is a change, the development of this variable is shown in the bottom left panel of figure 1. The variable capturing the amount that a household spends, simply takes on the value of the purchasing price of the new car. The bottom right panel of figure 1 shows the average development of the latter variable across households over the whole sample period $2^{2}$

How much can vehicle expenditures tell us about durable consumption? To answer this question, we take a look at the aggregate durable and vehicle expenditures in the Netherlands. The top left panel of figure 1 shows all subcategories of total durable consumption as defined by CBS, the Dutch statistical agency. Vehicle expenditures account for about $20 \%$ of total durable consumption in the Netherlands across the whole sample period. They are the second biggest component of durable consumption after textiles and clothing. Additionally, as the top right panel of figure 1 shows, they are highly correlated with total durable expenditures (correlation coefficient of 0,95 between 1995 and 2015).

\section{Inflation expectations}

In the DHS households are asked the following question about their expectations for one year ahead inflation:

What is the most likely (consumer)prices increase over the next twelve months, do you think?

Since 2008 the possible answers are between $1 \%$ to $10 \%$ in steps of one. Before, respondents were free to respond any number they liked. The left panel of figure 2 shows the development of this variable over time. There is a clear peak of inflation expectations after the introduction of the Euro. After that the downward trend in average expectations continues until well after 2008 and has stabilized close to but above $2 \%$ after that.

The right panel of figure 2 compares average expected inflation in the Netherlands with the realized

$\overline{2} \quad$ The peak in 2009 in the extensive margin is due to a car scrapping scheme implemented by the Dutch government as a response to the crisis of 2008. No corresponding peak is observed on the intensive margin. This means households did not buy more expensive cars due to the scrapping scheme, there were simply more households that bought a car in that year. We use year-fixed effects to account for such effects. 

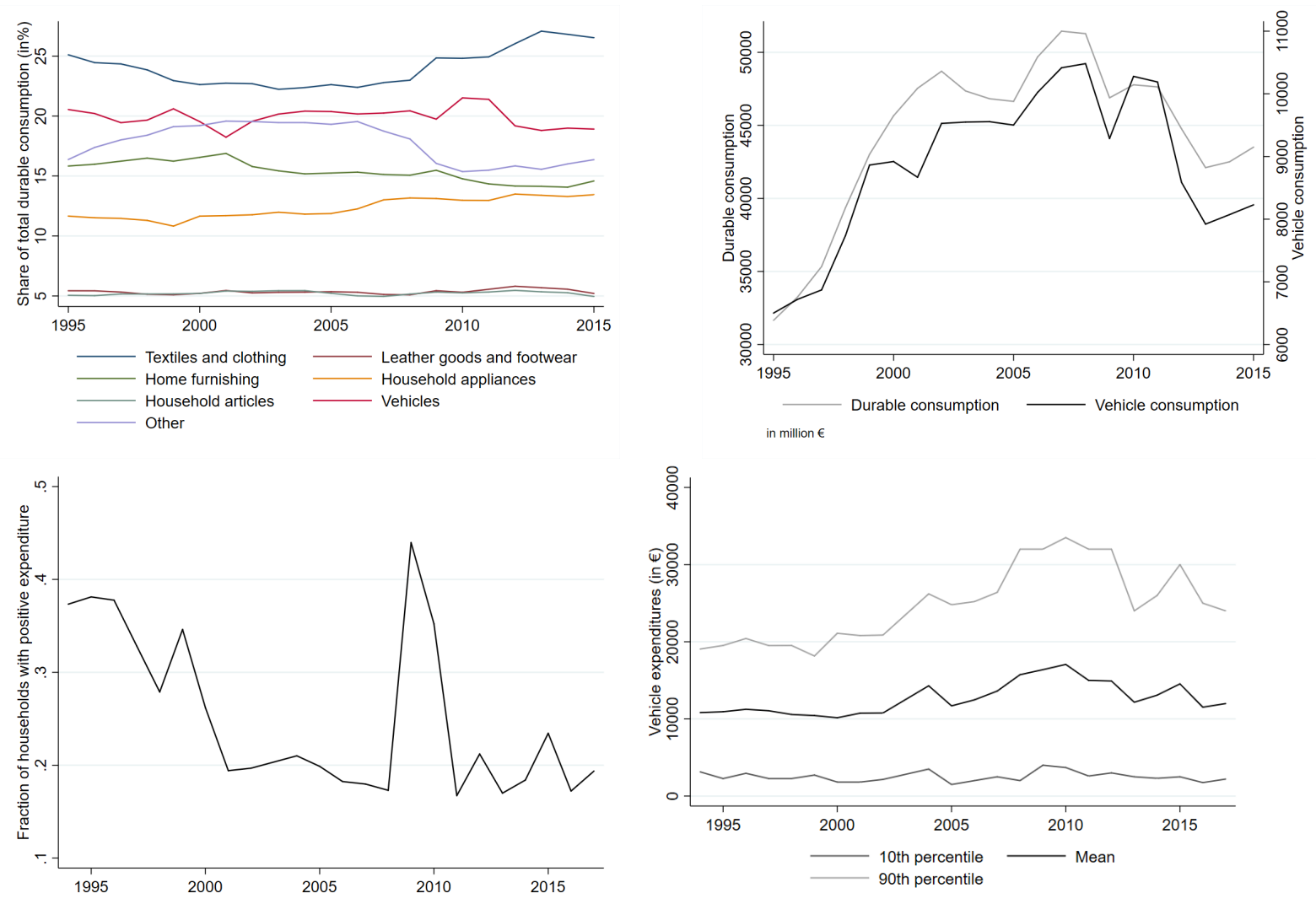

Figure 1: Top left panel: Subcategories of durable goods and their share in total durable goods expenditures (in \%). Top right panel: Total durable goods (left axis) and vehicle expenditures (right axis) (Source for both: CBS). Bottom left panel: Fraction of households with positive vehicle expenditures (extensive margin). Bottom right panel: Vehicle expenditures of households in our dataset (intensive margin) (both own calculations) 
CPI values. The figure shows that expected inflation is structurally higher than realized inflation but trends are well anticipated by households. The latter observation is more relevant for our study since we are mainly interested in changes in inflation expectations. Secondly, this alleviates concerns that inflation expectations by (laymen) survey respondents are completely detached from actual inflation and instead measure expectations or perceptions of some other variables. However, the two series are very synchronized and tend to exhibit peaks and troughs in the same periods. One would rather expect the survey responses to lead realized inflation since respondents are asked what they expect inflation to be over the coming 12 months. Note that this might very well be the case. If respondents' expectations for the coming 12 months are elicited in January of a given year (and these expectations turn out to be correct), this figure would suggest some degree of synchronization. The CPI value for that given year contains most of the 12 months that expectations were elicited for. Therefore, one cannot regard this figure as evidence that expectations merely reflect perceived inflation in a given period.
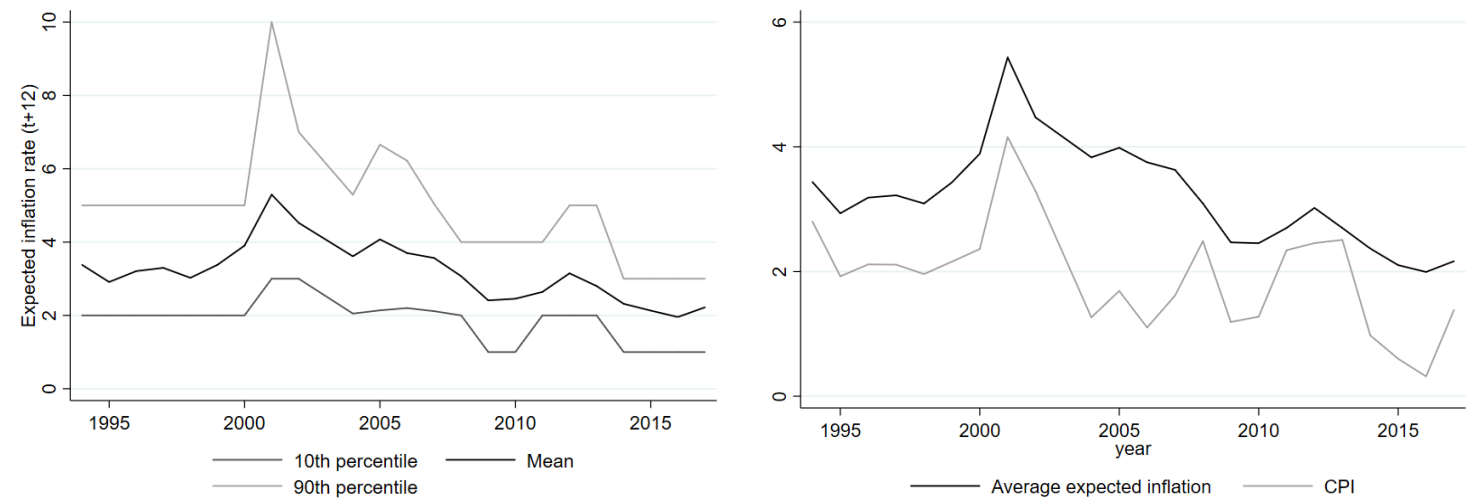

Figure 2: Left panel: Inflation expectations in DHS. Right panel: Inflation expectations in DHS and CPI growth in the Netherlands (in \%).

\section{Balance sheet}

Table 1 shows the single balance sheet components that households report as well as the aggregation level at which we include them in our models (in bold). Grouping of assets is largely determined by the liquidity of the balance sheet item. Among illiquid assets we differentiate between real estate and other assets to acknowledge the special role housing wealth could play. We group liabilities according to maturity. Mortgages and other longer term debt (referred to as loans) are aggregated separately. The net worth variable is constructed by subtracting liabilities from assets.

Instead of having to interpret our results in units of currency, we prefer to analyze percentage changes. The usual log-transformation is not well suited for our variables since many households do not possess some of the balance sheet variables. Their observations would be lost in case of a log-transformation. In 
the case of the net worth variable all negative net worth observations would be dropped as well. Instead, we perform an inverse hyperbolic sine transformation (ihs):

$$
x_{i}^{i h s}=\log \left(x_{i}+\left(x_{i}^{2}+1\right)^{\frac{1}{2}}\right)
$$

This transformation has been widely used in empirical work on household wealth (Burbidge et al. 1988 ; Pence, 2006). For values close to zero the transformation is approximately linear and resembles a logarithmic shape for larger absolute values. Table 2 gives descriptive statistics for all balance sheet variables that enter our regressions in the empirical analysis.

\begin{tabular}{|c|c|c|c|}
\hline Assets & & Liabilities & \\
\hline Cash & $\begin{array}{l}\text { Checking accounts } \\
\text { Savings/Deposit accounts } \\
\text { Deposit books }\end{array}$ & Loans & $\begin{array}{l}\text { Private loans } \\
\text { Loans from family/friends } \\
\text { Study loans }\end{array}$ \\
\hline $\begin{array}{l}\text { Financial } \\
\text { investments }\end{array}$ & $\begin{array}{l}\text { Growth funds } \\
\text { Mututal funds } \\
\text { Bonds } \\
\text { Stocks and shares }\end{array}$ & $\begin{array}{l}\text { Short term } \\
\text { debt }\end{array}$ & $\begin{array}{l}\text { Extended lines of credit } \\
\text { Finance debt } \\
\text { Credit card debt }\end{array}$ \\
\hline Real estate & $\begin{array}{l}\text { Real estate, for own use } \\
\text { Real estate, not for own use }\end{array}$ & Mortgages & $\begin{array}{l}\text { Mortgages on real estate, for own use } \\
\text { Mortgages on real estate, not for own use }\end{array}$ \\
\hline Other illiquid assets & $\begin{array}{l}\text { Employer-sponsored savings plans (ESSP) } \\
\text { Savings certificates } \\
\text { Single-premium annuity insurance policies (SPAI) } \\
\text { Savings or endowment insurance policies }\end{array}$ & & \\
\hline
\end{tabular}

Table 1: Balance sheet variables in the dataset and their aggregation in our analysis (in bold letters) 
Table 2: Descriptive statistics for ihs-transformed balance sheet variables. Overall contains statistics for pooled observations. Between compares averages across panel members. Within calculates statistics within panel members (global mean is added for min and max values of within statistics).

\begin{tabular}{|c|c|c|c|c|c|c|}
\hline Variable & Panel & Mean & $\mathrm{Sd}$ & Min & Max & Observations \\
\hline \multirow[t]{3}{*}{ Net worth } & Overall & 9.11 & 7.06 & -13.77 & 15.26 & $\mathrm{~N}=21654$ \\
\hline & Between & & 7.20 & -13.46 & 15.11 & $\mathrm{n}=6801$ \\
\hline & Within & & 3.45 & -14.75 & 28.77 & $\mathrm{~T}=3.18$ \\
\hline \multirow[t]{3}{*}{ Cash holdings } & Overall & 7.56 & 4.79 & -11.26 & 13.82 & $\mathrm{~N}=34812$ \\
\hline & Between & & 4.38 & -10.71 & 13.65 & $\mathrm{n}=9046$ \\
\hline & Within & & 2.84 & -10.60 & 24.70 & $\mathrm{~T}=3.85$ \\
\hline \multirow[t]{3}{*}{ Financial investments } & Overall & 2.12 & 4.20 & 0 & 14.29 & $\mathrm{~N}=31353$ \\
\hline & Between & & 3.61 & 0 & 13.89 & $\mathrm{n}=8871$ \\
\hline & Within & & 2.11 & -9.72 & 14.25 & $\mathrm{~T}=3.53$ \\
\hline \multirow[t]{3}{*}{ Real estate } & Overall & 8.65 & 6.28 & 0 & 15.82 & $\mathrm{~N}=26653$ \\
\hline & Between & & 6.18 & 0 & 15.30 & $\mathrm{n}=7259$ \\
\hline & Within & & 2.15 & -4.64 & 20.80 & $\mathrm{~T}=3.67$ \\
\hline \multirow[t]{3}{*}{ Illiquid assets } & Overall & 3.31 & 4.57 & 0 & 13.30 & $\mathrm{~N}=34819$ \\
\hline & Between & & 4.04 & 0 & 13.01 & $\mathrm{n}=9037$ \\
\hline & Within & & 2.64 & -7.20 & 14.86 & $\mathrm{~T}=3.85$ \\
\hline \multirow[t]{3}{*}{ Loans } & Overall & 0.98 & 2.92 & 0 & 12.51 & $\mathrm{~N}=34824$ \\
\hline & Between & & 3.08 & 0 & 12.51 & $\mathrm{n}=9005$ \\
\hline & Within & & 1.68 & -8.42 & 12.88 & $\mathrm{~T}=3.87$ \\
\hline \multirow[t]{3}{*}{ Short-term debt } & Overall & 1.22 & 3.07 & 0 & 11.94 & $\mathrm{~N}=34998$ \\
\hline & Between & & 2.91 & 0 & 11.81 & $\mathrm{n}=9049$ \\
\hline & Within & & 1.78 & -8.12 & 11.73 & $\mathrm{~T}=3.87$ \\
\hline \multirow[t]{3}{*}{ Mortgages } & Overall & 6.05 & 6.16 & 0 & 14.58 & $\mathrm{~N}=26554$ \\
\hline & Between & & 5.87 & 0 & 14.58 & $\mathrm{n}=7243$ \\
\hline & Within & & 2.77 & -6.32 & 18.02 & $\mathrm{~T}=3.67$ \\
\hline
\end{tabular}




\section{$5 \quad$ Empirical approach}

As pointed out in section 3, there are several arguments why inflation expectations could matter for spending decisions and how wealth could alter size and direction of this relation. In this section we translate these channels into expected results of our empirical analysis. We test those prediction both on the extensive and the intensive margin. For the extensive margin we analyze the binary decision of purchasing a vehicle or not. To that end, we run fixed effects logit regressions with the binary purchasing variable as dependent variable and inflation expectations, the balance sheet variable(s), current income, and expected income as independent variables. Additionally, we allow for the inclusion of relevant household characteristics - depending on the regression specification - as control variables (see the discussion about the selection of controls below). The intensive margin only concerns households with positive vehicle expenditures. Our objective is to find out what role the potential mechanisms play in determining the amount of money households spend on vehicles. In each case vehicle expenditures in logs are regressed on the same key independent variables as above (and additionally possible confounders) using fixed effects OLS.

Before outlining the predictions, we first motivate additional key decisions regarding our data and regression specification:

\subsection{Specification}

\section{Extensive margin}

We estimate the following conditional logit model (Wooldridge, 2010):

$$
\begin{gathered}
\operatorname{Pr}\left(c_{i t}=1 \mid E_{i t-1}\left(\pi_{t}\right), W_{i t-1}, \boldsymbol{X}_{i t-1}, \alpha_{i}, \kappa_{t}\right)= \\
\lambda\left(\sigma E_{i t-1}\left(\pi_{t}\right)+\delta E_{i t-1}\left(\pi_{t}\right) * \overline{W_{i}}+\phi W_{i t-1}+\boldsymbol{X}_{i t-1} \boldsymbol{\theta}+\alpha_{i}+\kappa_{t}\right),
\end{gathered}
$$

where $\alpha_{i}$ and $\kappa_{t}$ are household and year-fixed effects, $E_{i t-1}\left(\pi_{t}\right)$ is household $i^{\prime} s$ expectation at time $t-1$ for the inflation rate at time $t, \overline{W_{i}}$ household $i$ 's average value of the balance sheet variable, $W_{i t-1}$ that variable's value in $t-1$ and $\boldsymbol{X}_{i t-1}$ household $i$ 's set of other characteristics at time $t-13^{3} \lambda$ denotes the logistic function. The fixed effects logit model imposes the condition that $T>\sum_{t=1}^{T} c_{i t}>0$, where $T$ is the total number of periods that the household participated in the survey. This condition implies that only households whose expenditure variable takes on both possible values ( 0 and 1$)$ are included in the estimation.

$3 \quad$ We regard the year-specific wealth variable merely as a control variable since year-to-year changes in wealth could have effects on consumption that are independent of inflation expectations. 


\section{Intensive margin}

The following equation describes our basic fixed effects regression of positive vehicle expenditure on our variables of interest and controls.

$$
D C_{i t}=\alpha_{i}+\kappa_{t}+\sigma E_{i t-1}\left(\pi_{t}\right)+\delta E_{i t-1}\left(\pi_{t}\right) * \overline{W_{i}}+\phi W_{i t-1}+\mathbf{X}_{i t-1} \boldsymbol{\theta}+\epsilon_{i, t}
$$

where $D C_{i t}$ is household $i^{\prime} s$ vehicle expenditure measured at time $t, \alpha_{i}$ and $\kappa_{t}$ are household and yearfixed effects, $E_{i t-1}\left(\pi_{t}\right)$ is household $i^{\prime} s$ expectation at time $t-1$ for the inflation rate at time $t, \overline{W_{i}}$ household $i$ 's average value of the balance sheet variable, $W_{i t-1}$ that variable's value in $t-1, \mathbf{X}_{i t-1}$ a vector of control variables and $\epsilon_{i, t}$ the error term. We either include the aggregated balance sheet components presented in table 1 for $W_{i t-1}$ or net worth (i.e. assets - liabilities).

In both specifications, we compute the standard errors by bootstrapping. To take account of the time dimension panel members rather than individual observations are selected randomly.

\section{Interaction terms}

Interacting two time-varying, continuous variables in a panel analysis makes an economic interpretation of the resulting coefficient difficult. If both single variables change in the same direction the predicted effect of the interaction term on the outcome is the same irrespective of the direction of the change in the interacted variables. Additionally, recent research suggests that such an interaction term does not exclusively measure within variation of the interaction term (Giesselmann \& Schmidt-Catran, 2018). For these reasons, we choose to interact time-invariant balance sheet measures, specifically their household means, with expected inflation. Due to its time-invariance, no coefficient will be estimated for the household average. However, interacting the mean with expected inflation can capture differences in the effects of expected inflation on consumption across households with different balance sheet positions. For variables that can take on negative values on average, e.g. net worth, this approach does not solve the problem described in the beginning of the paragraph. The sign of the effect would be the same for rich households with positive changes in expected inflation and poor households with negative changes, no matter what the sign of the coefficient is. Thus, we measure the balance sheet variables on a strictly positive scale. For better readability in graphs and tables we re-transformed them after the estimation to take on negative values when they are in fact negative $4^{4}$ We can thus interpret the coefficients of the interaction terms as differences across households in the reaction of consumption to expected inflation determined by cross-sectional differences in their balance sheets.

Next, we discuss what we measure specifically with the different coefficients of interest and how this

$4 \quad$ This only applies to net worth and cash holdings. All other balance sheet variables take on strictly positive values anyway. Table 2 shows descriptive statistics for the balance sheet variables (for net worth and cash before transforming them to positive values). 
relates to the mechanisms we outlined earlier. Two coefficients in the above regressions are of special interest: $\sigma$, the coefficient for expected inflation, and $\delta$, the coefficient of the interaction term. $\sigma$ measures the effect of expected inflation on the consumption variable if the average value of the balance sheet variable for a household is equal to zero. Note that no balance sheet variable that enters a regression can take on negative values, i.e. an average of zero would imply a value of zero for each year-specific observation as well. As an example, consider our baseline regression in which we include net worth as balance sheet measure. Net worth is measured on a positive scale, zero is its lowest possible value. In this analysis $\sigma$ measures the consumption response to changes in expected inflation for the lowest possible net worth. Of course this is an unrealistic case. Most households have higher average net worth. The interaction coefficient, $\delta$, measures in which direction and with what magnitude net worth scales the effect of inflation expectations on consumption. When including single balance sheet components, $\sigma$ measures the effect of expected inflation on consumption if the household has no holdings of the balance sheet component. The interaction coefficient, $\delta$, measures in which direction and with what magnitude these components scale that effect. The mechanisms that we discussed in section 3 predict opposite effects of the interaction between wealth and expected inflation. That complicates the interpretation of our regression results. The coefficient of the interaction term is the average magnitude of the two channels. If it is significantly different from zero, one of the two effects dominates. However, this would not prove the absence of the other effect.

Table 3 gives an overview of the expected coefficients for the variables of interest in our regression if the channels could be measured separately. Thus, if the coefficients in our models align with the signs or magnitudes of these coefficients we could claim that the respective channel dominates over the other. As outlined in section 3 , we differentiate between two channels: the real interest rate channel and the real wealth channel. The two channels predict effects of opposite directions for the interaction between expected inflation and balance sheet variables. In our results section we present the coefficients of the extensive margin regressions in odds ratios. A positive effect is thus represented as an odds ratio larger than 1, a negative effect as an odds ratio lower than 1. As we argued in section 3 , the real interest rate channel predicts a positive effect of the interaction between expected inflation and household wealth, implying negative effects for any interaction between liabilities and expected inflation. For the real wealth channel, the predicted interaction effect between household wealth and expected inflation is negative. However, many assets serve as hedges against inflation. The real wealth channel on its own would thus predict no significant interaction effect when financial investments or real estate holdings are interacted separately with expected inflation. Any interaction between liabilities and expected inflation is expected to have positive effects on the spending variable. 


\begin{tabular}{lllc}
\hline Channel & Coefficient & \multicolumn{2}{c}{ Expected values } \\
& & \\
& & Extensive margin & Intensive margin \\
& & \\
\hline \multirow{2}{*}{ Real interest rate } & $\delta_{\text {net worth }}$ & $>1$ & $>0$ \\
& $\delta_{\text {assets }}$ & $>1$ & $>0$ \\
& $\delta_{\text {liabilities }}$ & $<1$ & $<0$ \\
Real wealth & $\delta_{\text {net worth }}$ & $<1$ & 0 \\
& $\delta_{\text {inflation hedges }}$ & 1 & $>0$ \\
& $\delta_{\text {liabilities }}$ & $>1$ & \\
\hline
\end{tabular}

Table 3: Predicted values of odds ratios (extensive margin) and coefficients (intensive margin) of the two competing channels for the interaction between the balance sheet variable and expected inflation $(\delta)$

\section{Timing of the households decision}

Figure 3 shows which period's observation of each of the previously introduced variables is used in our analysis. We only include households that are observed in at least two waves of the survey, otherwise we cannot determine differences (or lack thereof) in their vehicles' purchasing prices. Since we construct the expenditure variable by comparing purchasing prices of vehicles and do not use specific questions on the subject, we do not observe the exact date of the purchase. In our regressions we relate the vehicle purchase that occurred between period $t-1$ and $t$ to the balance sheet, inflation expectations and other characteristics observed in period $t-1$. Since households are asked about their expectations for the coming 12 months, we consider these 12 months as the current period in which the effect on spending should play out.

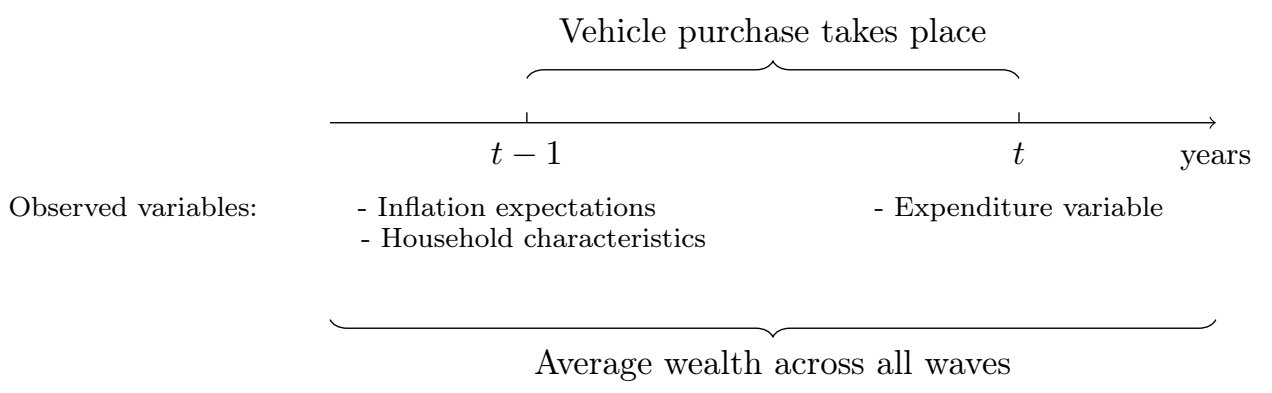

Figure 3: Timing of the household decision 


\section{Selection of controls}

Consumers' purchasing decisions are driven by many factors. We attempt to isolate the role of inflation expectations and various balance sheet items. However, if we do not control for other key predictors, estimation of the coefficients of interest may be biased. While it is plausible to assume that current and expected income are valid covariates in this context, the survey provides us with detailed information on individual household characteristics (e.g. attitudes toward saving and risk-taking, financial literacy, health, financial situation and expectations, etc.) and, hence, contain other possibly relevant predictors.

In order to identify relevant covariates, we use the "post-double-selection" method proposed by Belloni et al. (2014b). This involves a two-step LASSO regression, which in a first step selects covariates that predict the dependent variable, and in a second step selects variables predicting our independent variables of interest. The second step is necessary to control for the omitted variable bias. Note that selected controls may differ across regressions as we perform the "post-double-selection" for each regression separately. Table 6 in the appendix lists the selected control variables for each regression. In all cases we include current and expected income irrespective of whether they were selected in the variable selection procedure.

\section{Results}

\subsection{Extensive margin}

The analysis of the extensive margin of the household spending decision gives two main results: households that increase their inflation expectations over time become more likely to spend money on a vehicle. Moreover, this effect is stronger for households with lower average net worth. We find that this interaction is largely driven by the households in the lower part of the wealth distribution.

Our baseline regression for the extensive margin is a fixed effects logit regression in which we allow for an interaction between expected inflation and the average net worth of a household. The dependent variable takes on the value 0 in case a household did not purchase a car and 1 if it did. The complete results of our analysis of the extensive margin can be found in table 4 Figure 5 provides a visual representation of the coefficients. Conditional on a household's net worth, we find expected inflation to have a positive effect on the probability to consume at the $5 \%$ significance level. All else equal, for households with inflation expectations one percentage point above their within household mean the odds of positive vehicle expenditures increase by about $45 \%$.

Besides providing novel evidence of the relationship between expected inflation and consumer spending from a Euro area country, our main contribution lies in analyzing the interaction between inflation expectations and wealth. When using average net worth as an aggregate balance sheet measure we find 
a negative interaction effect with inflation expectations. The odds ratio for the interaction term is 0.988 and significant at the $10 \%$ level. An odds ratio lower than one implies that as the value of the interaction term increases, the odds of having positive vehicle expenditures fall. Thus, for households with higher average net worth, the predicted probability of consumption is lower than for low net worth households 5 Figure 4 visualizes the negative effect of the interaction between inflation expectations and average net worth. It shows the predicted probability of consumption conditional on a household's expected inflation and average net worth. The more we move towards the top left of the plot, the higher the probability for a household to have positive expenditures in a given year. For households with inflation expectations of $10 \%$ and a strongly negative net worth the predicted probability of purchasing a vehicle in the following period is between $60 \%$ and $70 \%$. In contrast, wealthier households with lower inflation expectations only have a predicted probability of consumption between $10 \%$ and $20 \%$. Additionally, as we move from the bottom right (high net worth, low inflation expectations) to the top left of the plot (low net worth, high inflation expectations) the effect of a change in one of the two variables on the predicted probability of consumption becomes stronger, visualized by the slices for each $10 \%$ probability interval becoming thinner ${ }^{6}$ Households at the bottom of the wealth distribution that adjust their inflation expectations upwards from an already high level of expectations are much more likely to purchase a vehicle than households with the same adjustment but high wealth.

How can these highly indebted households finance a vehicle purchase? Descriptive statistics can shed some light on this question. First, due to these households' likely limited access to external finance, we should expect them to buy less expensive vehicles. This is indeed the case: for households with negative net worth, the average purchasing price is only half that of the rest of the sample. Additionally, even though these households are net debtors, over $90 \%$ of them have positive cash balances. This suggests that they do have internal finance available to make a car purchase. Another frequently applied method of payment for cars is to include the old car in the payment for the new one, in which case even less cash would be necessary.

The right panel of figure 5 shows the coefficients of the included control variables. Neither current net income nor expected income have significant effects on the probability of positive vehicle expenditures. Additionally, the post double variable selection procedure did not select any of the household characteristics as additional control variables. A reason could be that many characteristics, such as financial literacy or household composition do not vary much for the limited time that we observe households. Variables that are more likely to vary, such as income, are already included by default.

The results from the net worth regressions give support to the real wealth channel presented in section

$5 \quad$ We measure net worth using positive numbers only. Thus, for net debtors the average net worth variable takes on positive values as well. This avoids the possibility of symmetric effects of the interaction term on consumption if both interacted variables have the same sign.

6 The plot should be interpreted by moving up or down for given levels of average household wealth since there is no within-household variation in the net worth variable. 
3. If the real wealth effect holds we should expect negative interaction effects between assets and expected inflation and positive effects for liabilities interacted with expected inflation. In case positive net worth households have investments that protect them against inflation - such as real estate or housing - we should only observe effects for liabilities. Given the granular balance sheet information we can test the real wealth channel in a more detailed manner. We ran seven separate regressions of the same type as for the analysis described above. Instead of using net worth as our balance sheet variable we included each aggregated balance sheet component from table1 1 separately and allowed for an interaction with expected inflation. We included the rest of the balance sheet components in our set of potential control variables. In the left panel we present the point estimates and confidence intervals for the interaction coefficients between the balance sheet variables and expected inflation. The right panel shows the point estimates and $90 \%$ confidence intervals for all control variables throughout the seven respective regressions. The complete regression results are presented in table 4

The strong positive effect of inflation expectations alone cannot be confirmed. While the point estimates of the odds ratios for expected inflation are larger or equal than one in most of the seven regressions, none of them is significantly larger than one. Lagged net income and expected income have very similar point estimates across all specifications but no significant effects. Consistent with our hypothesis, the point estimate of the odds ratio for the average cash/expected inflation interaction is smaller than one. However, the $90 \%$ confidence interval around the coefficient includes values larger than one. Additionally, we suggested that average liabilities should exhibit positive interaction effects. This is the case for short term debt and mortgages and again, the confidence interval is too wide to reject the possibility that the true effect is smaller than one at any reasonable level of certainty. For private loans the coefficient is even slightly lower than one, but neither significantly so. Regarding the remaining assets, there are no significant interaction effects neither. The odds ratio for average financial investments is the highest among all balance sheet interactions with a value of 1.012, but again we cannot claim significance of the result.

Thus, interacting sub components of the households' balance sheet with expected inflation does not contribute to a deeper understanding of the mechanism driving the "aggregate" effect observed before.

It should be noted that self-reported household data might also be subject to measurement error. Vellekoop \& Wiederholt (2017) have found differences between the self-reported wealth data in the DHS survey and administrative wealth data on the same households. Unfortunately, due to the relatively small number of vehicle purchases that we observe it was not possible to link the survey data to administrative wealth registers as Vellekoop \& Wiederholt (2017) have done and still have sufficient observations for our analysis. Thus for our analysis, measurement error might be especially relevant for the balance sheet components. The interaction coefficients of the balance sheet components and expected inflation tend to have wider confidence intervals than the interaction of net worth and expected inflation (see figure 5). An 
explanation for this could be that individual balance sheet components are much noisier signals about a household's financial situation than an aggregate measure such as net worth. As table 2 shows, the single balance sheet items tend to exhibit relatively high variation compared to net worth given their much narrower range of observed values. Upon aggregating the individual components some erratic behavior of these variables might disappear.

To summarize, our results on the extensive margin give some support to the conventionally expected effect of inflation expectations on spending, which suggests that higher inflation expectations lead to a higher probability to consume in the current period, at least when we include an aggregate balance sheet measure. The net worth regression also supports the real wealth channel, especially for debtors. At the same time it rejects a dominating role of the real interest channel. The regressions in which we include more granular balance sheet information cannot reject or confirm any of our predictions.

\subsection{Intensive margin}

On the intensive margin we test the same hypotheses as before. The dependent variable is log vehicle expenditures. Thus, we exclude observations of zero vehicle expenditures. This reduces our sample size considerably. The number of observations varies between 1262 (943 households) and 2594 (1542 households) across specifications due to the post double variable selection procedure and varying overlaps between control variables and our variables of interest. Again, our baseline model only includes household net worth as balance sheet variable. Figure 6 provides a visualization of the results and table 5 shows the detailed regression table. Contrary to our analysis on the extensive margin we don't find evidence for an interaction effect between average net worth and expected inflation. The point estimate of the interaction term is negative but too close to zero to claim a significant difference. Expected inflation alone has a slight positive but insignificant effect on log vehicle expenditures. Concerning the control variables results do not differ much from those on the extensive margin. Neither lagged net income nor expected income have significant effects.

Some differences appear when including single balance sheet components instead of net worth. As stated above, we include each single balance sheet item and its average value's interaction with expected inflation by default. The remaining balance sheet items are part of the potential control variables from which the post double variable selection procedure selects those variables that are relevant (see table A in the appendix). All of the interaction coefficients are very close to zero. Therefore, none of the three hypotheses seem to play a dominant role on the intensive margin. In the analysis of single components we do find that net current income has significant positive effects on the amount households spend on vehicles. The size of the effect is roughly similar for all components and also in line with the point 


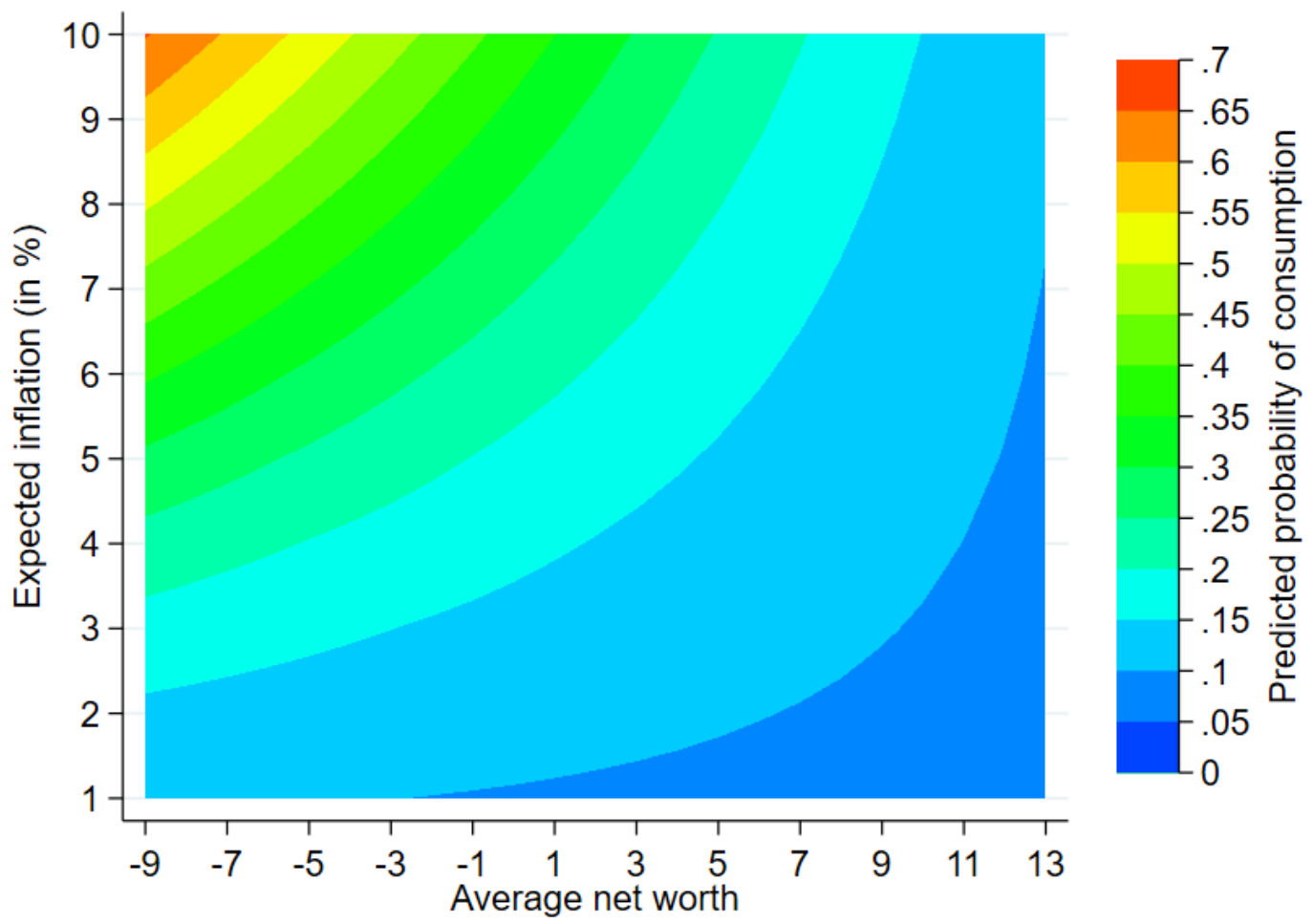

Obs: 2633

Figure 4: Plot of the predicted probability of positive vehicle expenditures given average net worth of the household and its inflation expectations. The predicted probabilities are obtained in the following way: for all combinations of a given grid of values for expected inflation (1 to 10 in intervals of 1) and the ihs-transformed net worth variable (-10 to 8 in intervals of 2 ) the plot shows the average predicted probability across the sample (not the predicted probability at the mean of the remaining covariates). Average net worth in the regression was measured using positive values only but retransformed to negative numbers for negative net worth for better readability. Each observation is treated as if the given values in the grids were the observed values for expected inflation and net worth. Then each household's predicted probability is computed based on the grid values and the remaining observed covariate values. The resulting probability in the graph is the average predicted probability for each combination across households. Additionally, the fixed effect for each household is set at 0 . 

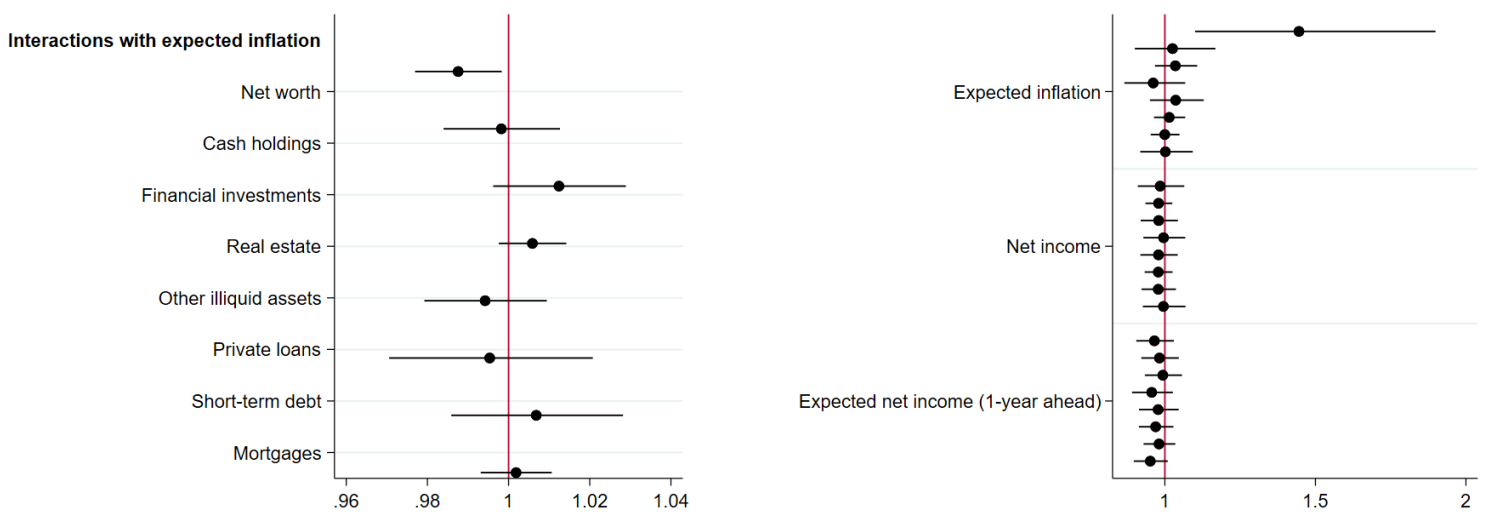

Figure 5: Results for extensive margin regressions. All coefficients are expressed in odds ratios. Left panel: Point estimates and 90\% confidence intervals for odds ratios of interaction terms between expected inflation and respective average value of balance sheet variable. Right panel: Point estimates and 90\% confidence intervals for expected inflation, net income and expected income coefficients obtained from separate regressions for each balance sheet variable interaction with expected inflation (in order of balance sheet variables in the left panel)
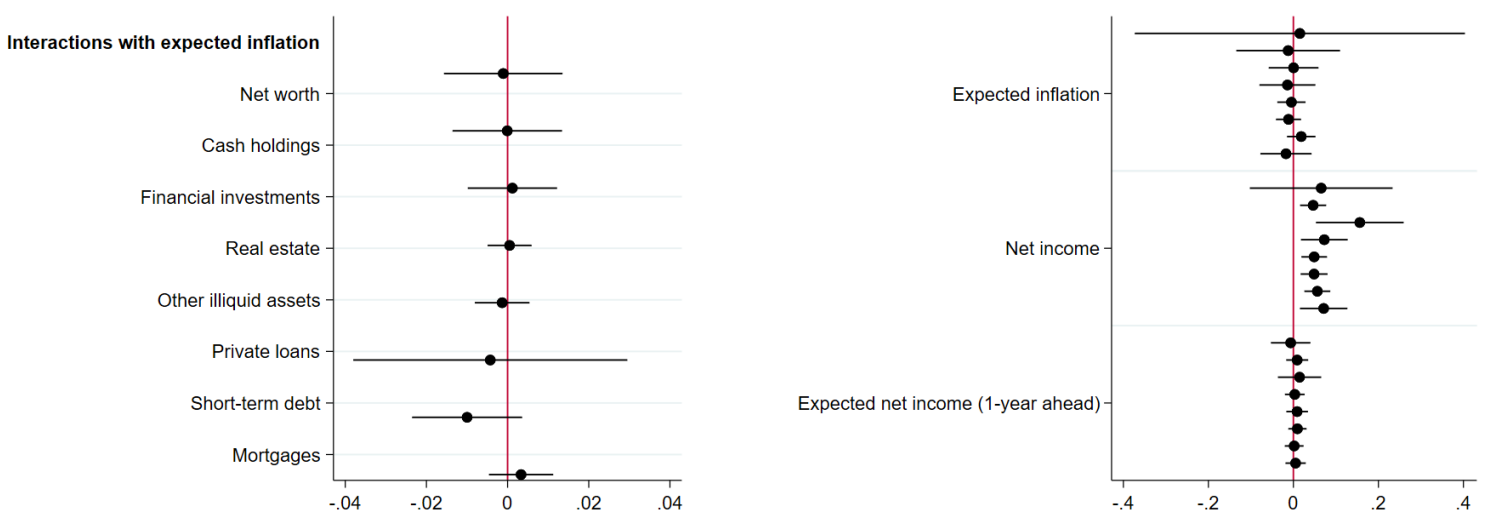

Figure 6: Results for intensive margin regressions. Left panel: Point estimates and 95\% confidence intervals for coefficients of interaction terms between expected inflation and respective average value of balance sheet variable. Right panel: Point estimates and 95\% confidence intervals for expected inflation, net income and expected income coefficients obtained from separate regressions for each balance sheet variable interaction with expected inflation (in order of balance sheet variables in the left panel) 
estimate for net income in the regression that included net worth as a balance sheet variable. A one percent increase in net current income is associated with an increase in vehicle expenditures of around 0.05\%. Expected income has no significant effect on spending.

\section{Conclusion}

In this paper we used uniquely detailed household balance sheet data to investigate a channel through which inflation expectations affect spending that has often been suggested in the literature but never thoroughly tested. Several authors have argued that wealth could mediate the spending reaction of individuals to their inflation expectations. We presented different hypotheses why this could be the case and tested them on Dutch household data. Our results do suggest a mediating role of the real wealth channel: the positive response of the probability to spend when inflation expectations increase is stronger for households with lower average net worth. Additionally, we find evidence that no single balance sheet category is driving this effect. This suggests that the net financial position is the more important determinant of household behavior.

The implications of our results for aggregate spending on durable goods are hard to quantify. As we have argued earlier, a reaction on the extensive margin likely affects aggregate spending more than on the intensive margin. The strong positive effect of inflation expectations on the probability to spend does give some support to those that encourage central banks to use inflation expectations as a policy tool to boost demand. The differential effects of expectations across the wealth distribution, however, dampen the validity of this prescription. Households with high amounts of debt and substantially overestimated inflation expectations seem to be especially sensitive to their expectations and thus commit costly mistakes if inflation does not live up to their expectations (which it did not throughout our sample). Here, our study connects well to Vellekoop \& Wiederholt (2017). These authors show that households with higher inflation expectations have lower net worth and are less likely to own non-liquid assets, such as bonds, stocks or real estate. The remaining, inflation-sensitive balance sheet components have much higher relative importance than for households with lower inflation expectations. One conclusion for policy is therefore to improve the accuracy of households' inflation expectations. Recent research has shown that this can be done in two ways. More financially literate individuals tend to be better at forecasting inflation (Bruine de Bruin et al. 2010). At the same time, central banks themselves can contribute to better formation of expectations. Coibion et al. (2019) show that providing survey respondents with details about FOMC meetings substantially improves the accuracy of their inflation forecasts. The effect is equally strong whether latest inflation figures and interest rate changes are distributed or the entire minutes of the latest FOMC meeting. Providing easy-to-read newspaper articles on the same meetings has much weaker effects. Better central bank communication can thus play an important role in improving 
Table 4: Binary dependent variable for vehicle purchase (=1 in case purchase took place). Separate conditional logit for each balance sheet variable's interaction with expected inflation, coefficients expressed in odds ratios. Interaction term with average value of each household for balance sheet variable [back to the text (subsection 6.1]]

\begin{tabular}{|c|c|c|c|c|c|c|c|c|}
\hline & (1) & $(2)$ & (3) & (4) & $(5)$ & $(6)$ & $(7)$ & $(8)$ \\
\hline $\begin{array}{l}\text { Expenditures (=1 if } \mathrm{c}>0) \\
\text { Expected inflation }(\mathrm{L} 1)\end{array}$ & $\begin{array}{l}1.445^{* *} \\
(0.240)\end{array}$ & $\begin{array}{c}1.025 \\
(0.0811)\end{array}$ & $\begin{array}{c}1.035 \\
(0.0427)\end{array}$ & $\begin{array}{c}0.961 \\
(0.0613)\end{array}$ & $\begin{array}{c}1.036 \\
(0.0543)\end{array}$ & $\begin{array}{c}1.014 \\
(0.0315)\end{array}$ & $\begin{array}{c}1.000 \\
(0.0290)\end{array}$ & $\begin{array}{c}1.002 \\
(0.0530)\end{array}$ \\
\hline Net income (L1) & $\begin{array}{c}0.984 \\
(0.0469)\end{array}$ & $\begin{array}{c}0.979 \\
(0.0271)\end{array}$ & $\begin{array}{c}0.979 \\
(0.0376)\end{array}$ & $\begin{array}{c}0.996 \\
(0.0423)\end{array}$ & $\begin{array}{c}0.979 \\
(0.0377)\end{array}$ & $\begin{array}{c}0.978 \\
(0.0282)\end{array}$ & $\begin{array}{c}0.978 \\
(0.0347)\end{array}$ & $\begin{array}{c}0.995 \\
(0.0430)\end{array}$ \\
\hline Expected income (L1) & $\begin{array}{c}0.965 \\
(0.0379)\end{array}$ & $\begin{array}{c}0.982 \\
(0.0378)\end{array}$ & $\begin{array}{c}0.993 \\
(0.0374)\end{array}$ & $\begin{array}{c}0.956 \\
(0.0412)\end{array}$ & $\begin{array}{c}0.978 \\
(0.0400)\end{array}$ & $\begin{array}{c}0.969 \\
(0.0348)\end{array}$ & $\begin{array}{c}0.981 \\
(0.0321)\end{array}$ & $\begin{array}{c}0.952 \\
(0.0343)\end{array}$ \\
\hline Net worth (L1) & $\begin{array}{c}0.983 \\
(0.0138)\end{array}$ & & & & & & & \\
\hline Cash holdings (L1) & & $\begin{array}{c}1.005 \\
(0.0132)\end{array}$ & & & & & & \\
\hline Financial investments (L1) & & & $\begin{array}{c}1.017 \\
(0.0197)\end{array}$ & & & & & \\
\hline Real estate (L1) & & & & $\begin{array}{c}1.008 \\
(0.0147)\end{array}$ & & & & \\
\hline Illiquid assets (L1) & & & & & $\begin{array}{c}0.990 \\
(0.0128)\end{array}$ & & & \\
\hline Loans (L1) & & & & & & $\begin{array}{c}1.007 \\
(0.0169)\end{array}$ & & \\
\hline Short-term debt (L1) & & & & & & & $\begin{array}{c}0.972 \\
(0.0198)\end{array}$ & \\
\hline Mortgages (L1) & & & & & & & & $\begin{array}{c}1.016 \\
(0.0125)\end{array}$ \\
\hline$\overline{\text { Net worth }} \times$ Expected inflation (L1) & $\begin{array}{c}0.988^{*} \\
(0.00649)\end{array}$ & & & & & & & \\
\hline$\overline{\text { Cash }} \times$ Expected inflation (L1) & & $\begin{array}{c}0.998 \\
(0.00872)\end{array}$ & & & & & & \\
\hline$\overline{\text { Financial }} \times$ Expected inflation $(\mathrm{L} 1)$ & & & $\begin{array}{c}1.012 \\
(0.00994)\end{array}$ & & & & & \\
\hline$\overline{\text { Realestate }} \times$ Expected inflation (L1) & & & & $\begin{array}{c}1.006 \\
(0.00506)\end{array}$ & & & & \\
\hline$\overline{\text { Illiquid }} \times$ Expected inflation (L1) & & & & & $\begin{array}{c}0.994 \\
(0.00916)\end{array}$ & & & \\
\hline$\overline{\text { Loans }} \times$ Expected inflation (L1) & & & & & & $\begin{array}{c}0.995 \\
(0.0153)\end{array}$ & & \\
\hline$\overline{\text { Short }- \text { term debt }} \times$ Expected inflation (L1) & & & & & & & $\begin{array}{c}1.007 \\
(0.0129)\end{array}$ & \\
\hline$\overline{\text { Mortgages }} \times$ Expected inflation (L1) & & & & & & & & $\begin{array}{c}1.002 \\
(0.00532)\end{array}$ \\
\hline Household FE & Yes & Yes & Yes & Yes & Yes & Yes & Yes & Yes \\
\hline Year FE & Yes & Yes & Yes & Yes & Yes & Yes & Yes & Yes \\
\hline Lasso-selected controls & No & No & No & No & No & No & No & No \\
\hline Observations & 2633 & 5632 & 3476 & 4894 & 5630 & 5656 & 5671 & 4866 \\
\hline Households & 635 & 1066 & 818 & 940 & 1068 & 1071 & 1075 & 931 \\
\hline
\end{tabular}


Table 5: Dependent variable: Log vehicle expenditures. Separate fixed effects OLS regression for each average balance sheet item's interaction with expected inflation. Interaction term with average value of each household for balance sheet variable. [back to the text (subsection 6.2p]

\begin{tabular}{|c|c|c|c|c|c|c|c|c|}
\hline & (1) & $(2)$ & (3) & (4) & (5) & (6) & (7) & (8) \\
\hline Expected inflation (L1) & $\begin{array}{l}0.0152 \\
(0.236)\end{array}$ & $\begin{array}{c}-0.0123 \\
(0.0742)\end{array}$ & $\begin{array}{c}0.000462 \\
(0.0356)\end{array}$ & $\begin{array}{c}-0.0141 \\
(0.0400)\end{array}$ & $\begin{array}{r}-0.00462 \\
(0.0202)\end{array}$ & $\begin{array}{c}-0.0115 \\
(0.0180)\end{array}$ & $\begin{array}{c}0.0184 \\
(0.0204)\end{array}$ & $\begin{array}{c}-0.0174 \\
(0.0366)\end{array}$ \\
\hline Net income (L1) & $\begin{array}{l}0.0654 \\
(0.102)\end{array}$ & $\begin{array}{c}0.0465^{* *} \\
(0.0187)\end{array}$ & $\begin{array}{c}0.156^{* *} \\
(0.0627)\end{array}$ & $\begin{array}{c}0.0727^{* *} \\
(0.0334)\end{array}$ & $\begin{array}{c}0.0490^{* * *} \\
(0.0184)\end{array}$ & $\begin{array}{c}0.0487^{* *} \\
(0.0193)\end{array}$ & $\begin{array}{c}0.0563^{* * *} \\
(0.0186)\end{array}$ & $\begin{array}{c}0.0712^{* *} \\
(0.0340)\end{array}$ \\
\hline Expected income (L1) & $\begin{array}{r}-0.00640 \\
(0.0282)\end{array}$ & $\begin{array}{r}0.00894 \\
(0.0157)\end{array}$ & $\begin{array}{c}0.0145 \\
(0.0310)\end{array}$ & $\begin{array}{c}0.00326 \\
(0.0142)\end{array}$ & $\begin{array}{c}0.00882 \\
(0.0155)\end{array}$ & $\begin{array}{c}0.00952 \\
(0.0131)\end{array}$ & $\begin{array}{c}0.00187 \\
(0.0135)\end{array}$ & $\begin{array}{c}0.00518 \\
(0.0145)\end{array}$ \\
\hline Net worth (L1) & $\begin{array}{r}0.00499 \\
(0.0116)\end{array}$ & & & & & & & \\
\hline Cash holdings (L1) & & $\begin{array}{l}-0.00447 \\
(0.00567)\end{array}$ & & & & & & \\
\hline Financial investments (L1) & & & $\begin{array}{c}-0.0136 \\
(0.00998)\end{array}$ & & & & & \\
\hline Real estate (L1) & & & & $\begin{array}{c}0.00772 \\
(0.00961)\end{array}$ & & & & \\
\hline Illiquid assets (L1) & & & & & $\begin{array}{c}0.00244 \\
(0.00801)\end{array}$ & & & \\
\hline Loans (L1) & & & & & & $\begin{array}{c}0.00555 \\
(0.0118)\end{array}$ & & \\
\hline Short-term debt (L1) & & & & & & & $\begin{array}{c}0.00204 \\
(0.00955)\end{array}$ & \\
\hline Mortgages (L1) & & & & & & & & $\begin{array}{c}-0.00249 \\
(0.00644)\end{array}$ \\
\hline$\overline{\text { Net worth }} \times$ Expected inflation (L1) & $\begin{array}{l}-0.00107 \\
(0.00888)\end{array}$ & & & & & & & \\
\hline$\overline{\text { Cash }} \times$ Expected inflation (L1) & & $\begin{array}{c}-0.0000779 \\
(0.00820)\end{array}$ & & & & & & \\
\hline$\overline{\text { Financial }} \times$ Expected inflation $(\mathrm{L} 1)$ & & & $\begin{array}{c}0.00119 \\
(0.00669)\end{array}$ & & & & & \\
\hline$\overline{\text { Realestate }} \times$ Expected inflation (L1) & & & & $\begin{array}{c}0.000492 \\
(0.00330)\end{array}$ & & & & \\
\hline$\overline{\text { Illiquid }} \times$ Expected inflation (L1) & & & & & $\begin{array}{l}-0.00134 \\
(0.00410)\end{array}$ & & & \\
\hline$\overline{\text { Loans }} \times$ Expected inflation (L1) & & & & & & $\begin{array}{r}-0.00426 \\
(0.0205)\end{array}$ & & \\
\hline$\overline{\text { Short }- \text { term debt }} \times$ Expected inflation (L1) & & & & & & & $\begin{array}{l}-0.00998 \\
(0.00824)\end{array}$ & \\
\hline$\overline{\text { Mortgages }} \times$ Expected inflation (L1) & & & & & & & & $\begin{array}{c}0.00332 \\
(0.00482)\end{array}$ \\
\hline Constant & $\begin{array}{c}8.021^{* * *} \\
(1.169)\end{array}$ & $\begin{array}{c}8.472^{* * *} \\
(0.284)\end{array}$ & $\begin{array}{c}7.112^{* * *} \\
(0.748)\end{array}$ & $\begin{array}{c}8.168^{* * *} \\
(0.444)\end{array}$ & $\begin{array}{c}8.414^{* * *} \\
(0.299)\end{array}$ & $\begin{array}{c}8.383^{* * *} \\
(0.257)\end{array}$ & $\begin{array}{c}8.256^{* * *} \\
(0.266)\end{array}$ & $\begin{array}{c}8.129^{* * *} \\
(0.418)\end{array}$ \\
\hline Household FE & Yes & Yes & Yes & Yes & Yes & Yes & Yes & Yes \\
\hline Year FE & Yes & Yes & Yes & Yes & Yes & Yes & Yes & Yes \\
\hline Lasso-selected controls & Yes & Yes & Yes & Yes & Yes & Yes & Yes & No \\
\hline Observations & 1262 & 2431 & 1589 & 2166 & 2419 & 2424 & 2591 & 2275 \\
\hline Households & 943 & 1465 & 1153 & 1313 & 1462 & 1466 & 1540 & 1360 \\
\hline $\mathrm{R}^{2}$ & 0.0682 & 0.0655 & 0.0793 & 0.0727 & 0.0616 & 0.0679 & 0.0569 & 0.0657 \\
\hline
\end{tabular}

Standard errors in parentheses
${ }^{*} p<0.10,{ }^{* *} p<0.05,{ }^{* * *} p<0.01$ 
household expectations. An interesting question that arises from these results is whether households that improved their inflation forecasting also adapt their spending decisions accordingly. 


\section{References}

Anari, A. \& Kolari, J. (2002). House Prices and Inflation. Real Estate Economics, 30(1), 67-84.

Bachmann, R., Berg, T. O., \& Sims, E. R. (2015). Inflation expectations and readiness to spend: Cross-sectional evidence. American Economic Journal: Economic Policy, 7(1), 1-35.

Belloni, A., Chernozhukov, V., \& Hansen, C. (2014a). High-dimensional methods and inference on structural and treatment effects. Journal of Economic Perspectives, 28(2), 29-50.

Belloni, A., Chernozhukov, V., \& Hansen, C. (2014b). Inference on treatment effects after selection among high-dimensional controls. The Review of Economic Studies, 81(2), 608-650.

Bernanke, B. S. (1993). Credit in the Macroeconomy. Quarterly Review-Federal Reserve Bank of New York, 18, $50-50$.

Bruine de Bruin, W., VanderKlaauw, W., Downs, J. S., Fischhoff, B., Topa, G., \& Armantier, O. (2010). Expectations of inflation: The role of demographic variables, expectation formation, and financial literacy. Journal of Consumer Affairs, 44(2), 381-402.

Burbidge, J. B., Magee, L., \& Robb, A. L. (1988). Alternative transformations to handle extreme values of the dependent variable. Journal of the American Statistical Association, 83(401), 123-127.

Burke, M. A. \& Ozdagli, A. (2013). Household inflation expectations and consumer spending: evidence from panel data. Working papers, Federal Reserve Bank of Boston.

Case, K. E., Quigley, J. M., \& Shiller, R. J. (2005). Comparing wealth effects: the stock market versus the housing market. Advances in macroeconomics, 5(1).

Cavallo, A., Cruces, G., \& Perez-Truglia, R. (2017). Inflation expectations, learning, and supermarket prices: Evidence from survey experiments. American Economic Journal: Macroeconomics, 9(3), 1-35.

Christiano, L. J., Eichenbaum, M., \& Evans, C. L. (2005). Nominal rigidities and the dynamic effects of a shock to monetary policy. Journal of political Economy, 113(1), 1-45.

Coibion, O. \& Gorodnichenko, Y. (2012). What can survey forecasts tell us about information rigidities? Journal of Political Economy, 120(1), 116-159.

Coibion, O. \& Gorodnichenko, Y. (2015a). Information rigidity and the expectations formation process: A simple framework and new facts. American Economic Review, 105(8), 2644-78.

Coibion, O. \& Gorodnichenko, Y. (2015b). Is the Phillips curve alive and well after all? Inflation expectations and the missing disinflation. American Economic Journal: Macroeconomics, 7(1), 197-232.

Coibion, O., Gorodnichenko, Y., \& Kamdar, R. (2017). The Formation of Expectations, Inflation and the Phillips Curve. NBER Working Paper, (No. 23304). 
Coibion, O., Gorodnichenko, Y., \& Weber, M. (2019). Monetary policy communications and their effects on household inflation expectations. NBER Working Paper, (No. 25482).

D'Acunto, F., Hoang, D., \& Weber, M. (2016). Unconventional Fiscal Policy, Inflation Expectations, and Consumption Expenditure. SSRN Scholarly Paper ID 2760238, Social Science Research Network, Rochester, NY.

Duca, I. A., Kenny, G., \& Reuter, A. (2018). Inflation expectations, consumption and the lower bound: micro evidence from a large euro area survey. ECB Working Paper Series, No 2196.

Fama, E. F. \& Schwert, G. W. (1977). Asset returns and inflation. Journal of financial economics, 5(2), 115-146.

Giesselmann, M. \& Schmidt-Catran, A. (2018). Interactions in Fixed Effects Regression Models. Technical report, DIW Berlin, German Institute for Economic Research.

Hoesli, M., Lizieri, C., \& MacGregor, B. (2008). The Inflation Hedging Characteristics of US and UK Investments: A Multi-Factor Error Correction Approach. The Journal of Real Estate Finance and Economics, 36(2), $183-206$.

Ichiue, H. \& Nishiguchi, S. (2015). Inflation expectations and consumer spending at the zero bound: Micro evidence. Economic Inquiry, 53(2), 1086-1107.

Kim, S. \& In, F. (2005). The relationship between stock returns and inflation: new evidence from wavelet analysis. Journal of Empirical Finance, 12(3), 435-444.

Liu, L. Q., Wang, L., \& Wright, R. (2011). On the "hot potato" effect of inflation: Intensive versus extensive margins. Macroeconomic Dynamics, 15(S2), 191-216.

Mian, A., Rao, K., \& Sufi, A. (2013). Household balance sheets, consumption, and the economic slump. The Quarterly Journal of Economics, 128(4), 1687-1726.

Pence, K. M. (2006). The role of wealth transformations: An application to estimating the effect of tax incentives on saving. The BE Journal of Economic Analysis 8 Policy, 5(1).

Schotman, P. C. \& Schweitzer, M. (2000). Horizon sensitivity of the inflation hedge of stocks. Journal of empirical Finance, 7(3-4), 301-315.

Vellekoop, N. \& Wiederholt, M. (2017). Inflation Expectations and Choices of Households. Goethe University Frankfurt mimeo.

Wiederholt, M. (2014). Empirical properties of inflation expectations and the zero lower bound. Goethe University Frankfurt.

Wooldridge, J. M. (2010). Econometric analysis of cross section and panel data. MIT press. 


\section{Appendices}

\section{A Selected controls}

Table 6: Selected control variables. Each row refers to the regression in which the mentioned balance sheet variable and its interaction with expected inflation is included by default. Checkmarks indicate the selection of a control variable in the respective regression. In the extensive margin regressions no control variables were selected. [back to the text (subsection 6.2]]

\begin{tabular}{|c|c|c|c|c|}
\hline & $\begin{array}{l}\text { Income unusually } \\
\text { high or low? }\end{array}$ & $\begin{array}{l}\text { Need to take } \\
\text { fin. risks } \\
\text { to improve } \\
\text { fin. position }\end{array}$ & $\begin{array}{l}\text { Household } \\
\text { composition }\end{array}$ & $\begin{array}{l}\text { Prepared to take } \\
\text { risks when there } \\
\text { is chance to gain }\end{array}$ \\
\hline$\overline{\text { Net worth }}$ & $\checkmark$ & & & \\
\hline$\overline{\text { Cash holdings }}$ & & $\checkmark$ & & \\
\hline$\overline{\text { Financial investments }}$ & $\checkmark$ & & & \\
\hline$\overline{\text { Real estate }}$ & & & & $\checkmark$ \\
\hline$\overline{\text { Other illiquid assets }}$ & & $\checkmark$ & & \\
\hline$\overline{\text { Private loans }}$ & & $\checkmark$ & & \\
\hline$\overline{\text { Short term debt }}$ & & $\checkmark$ & $\checkmark$ & \\
\hline
\end{tabular}

\section{Survey questions for selected controls}

Question: Is this income unusually high or low compared to the income you would expect in a regular year, or is it regular?

Responses: unusually low, regular, unusually high

Question: Please indicate on a scale from 1 to 7 to what extent you agree with the statement $(1=$ totally disagree, $7=$ totally agree): If I want to improve my financial position, I should take financial risks.

Question: Composition of the household. The respondent...

Responses: ... is living by himself/herself; is living together with partner, no child(ren) living at home; is living together with partner, child(ren) living at home; is living without a partner, but with child(ren); other

Question: Please indicate on a scale from 1 to 7 to what extent you agree with the statement $(1=$ totally disagree, $7=$ totally agree): I am prepared to take the risk to lose money, when there is also a chance to gain money. 